\title{
Feeding of a deep-fried fat causes PPAR $\alpha$ activation in the liver of pigs as a non-proliferating species
}

\author{
Sebastian Luci ${ }^{1}$, Bettina König ${ }^{1}$, Beatrice Giemsa ${ }^{1}$, Stefanie Huber ${ }^{1}$, Gerd Hause ${ }^{2}$, Holger Kluge ${ }^{1}$, \\ Gabriele I. Stangl ${ }^{1}$ and Klaus Eder ${ }^{1 *}$ \\ ${ }^{1}$ Institute of Agricultural and Nutritional Sciences, Martin-Luther-University of Halle-Wittenberg, Emil-Abderhalden-Strasse 26, \\ D-06108 Halle (Saale), Germany \\ ${ }^{2}$ Biocenter, Martin-Luther-University of Halle-Wittenberg, Weinbergweg 22, D-06120 Halle (Saale), Germany
}

(Received 24 August 2006 - Revised 20 November 2006 - Accepted 8 December 2006)

\begin{abstract}
Recent studies have shown that dietary oxidised fats influence the lipid metabolism in rats by activation of PPAR $\alpha$. In this study, we investigated whether a mildly oxidised fat causes activation of PPAR $\alpha$ in pigs which are non-proliferators like man. Eighteen pigs were assigned to two groups and received either a diet containing $90 \mathrm{~g} / \mathrm{kg}$ of a fresh fat or the same diet with $90 \mathrm{~g} / \mathrm{kg}$ of an oxidised fat prepared by heating for $24 \mathrm{~h}$ at $180^{\circ} \mathrm{C}$ in a deep fryer. Pigs fed the oxidised fat had a higher peroxisome count, a higher activity of catalase and a higher mRNA concentration of mitochondrial 3-hydroxy-3-methylglutaryl-CoA synthase in the liver and a higher concentration of 3-hydroxybutyrate in plasma than pigs fed the fresh fat $(P<0 \cdot 05)$. Hepatic mRNA concentrations of acyl-CoA oxidase and carnitine palmitoyltransferase-1 tended to be increased in pigs fed the oxidised fat compared to pigs fed the fresh fat $(P<0 \cdot 10)$. Pigs fed the oxidised fat, moreover, had higher mRNA concentrations of sterol regulatory elementbinding protein (SREBP)-1 and its target genes acetyl-CoA carboxylase and stearoyl-CoA desaturase in the liver and higher mRNA concentrations of SREBP-2 and its target genes 3-hydroxy-3-methylglutary-CoA reductase and LDL receptor in liver and small intestine. In conclusion, this study shows that even a mildly oxidised fat causes activation of PPAR $\alpha$ in the liver of pigs. Up-regulation of SREBP and its target genes in liver and small intestine suggests that the oxidised fat could stimulate synthesis of cholesterol and TAG in these tissues.
\end{abstract}

Oxidised fat: Pig: PPAR $\alpha$ : Cholesterol: Triacylglycerols

The typical western diet contains large quantities of PUFA that are heated or processed to varying degrees. In fast-food restaurants fat is heated in fryers for up to $18 \mathrm{~h}$ daily, at temperatures close to $180^{\circ} \mathrm{C}$ (Frankel et al. 1984). Several studies with animals have been performed to investigate the effects of oxidised fats on the metabolism (reviewed in Cohn, 2002). Recently, it has been shown in rats that oxidised fats are able to influence the lipid metabolism by activation of PPAR $\alpha$ (Chao et al. 2001, 2004, 2005; Sülzle et al. 2004), a transcription factor belonging to the nuclear hormone receptor superfamily (Schoonjans et al. 1996). This is probably due to the occurrence of hydroxy- and hydroperoxy fatty acids such as hydroxy octadecadienoic acid and hydroperoxy octadecadienoic acid which are potent activators of PPAR $\alpha$ (Delerive et al. 2000; Mishra et al. 2004; König \& Eder, 2006). Activation of PPAR $\alpha$ leads to an increase in the transcription of genes related to fatty acid transport across the cell membrane, intracellular lipid trafficking, mitochondrial and peroxisomal fatty acid uptake, and both mitochondrial and peroxisomal fatty acid $\beta$-oxidation, gluconeogenesis and ketogenesis
(Mandard et al. 2004). Recently, it has been shown that $\operatorname{PPAR} \alpha$ activation influences also the expression or the proteolytic activation of sterol regulatory element-binding proteins (SREBP), transcription factors which control fatty acid synthesis and cholesterol homeostasis (Patel et al. 2001; Guo et al. 2001; Knight et al. 2005; König et al. 2006). Therefore, $\operatorname{PPAR} \alpha$ activation stimulates not only the degradation of fatty acids by enhancing $\beta$-oxidation but affects also the synthesis of cholesterol and TAG. Reduced liver and plasma concentrations of TAG and cholesterol are typical effects observed in animals treated with PPAR $\alpha$ agonists, and such effects have been also observed in rats administered oxidised fats (Huang et al. 1988; Eder \& Kirchgessner, 1998; Eder, 1999; Chao et al. 2001, 2004, 2005; Sülzle et al. 2004).

Regarding the expression of PPAR $\alpha$ in tissues and the effects of PPAR $\alpha$ activation on transcription of its target genes, there are great differences between various species. In rodents, PPAR $\alpha$ is highly expressed, and activation of $\operatorname{PPAR} \alpha$ not only induces many genes involved in various metabolic pathways such as $\beta$-oxidation, ketogenesis and

\footnotetext{
Abbreviations: ACC, acetyl-CoA carboxylase; ACO, acyl-CoA oxidase; CPT-1, carnitine palmitoyltransferase-1; CYP7, cholesterol 7 $\alpha$-hydroxylase; HMG-CoA-R, 3-hydroxy-3-methylglutaryl-CoA reductase; L-FABP, liver fatty acid binding protein; mHMG-CoA-S, mitochondrial 3-hydroxy-3-methylglutaryl-CoA synthase; MTP, microsomal TAG transfer protein; SCD, stearoyl-CoA desaturase; SOD, superoxide dismutase; SREBP, sterol regulatory element-binding protein; TBARS, thiobarbituric acid-reactive substances.

* Corresponding author: Prof. Dr K. Eder, fax +49345 5527124, email klaus.eder@landw.uni-halle.de
} 
gluconeogenesis but also causes severe peroxisome proliferation in the liver (Peters et al. 2005). In contrast to rodents, $\operatorname{PPAR} \alpha$ agonists do not induce peroxisome proliferation in the liver of many other species, such as guinea pigs, swine, monkeys and man (Holden \& Tugwood, 1999). These nonproliferating species have a lower expression of PPAR $\alpha$ in the liver and the response of many genes to PPAR $\alpha$ activation is much weaker than in proliferating species. For that reason, effects related to PPAR $\alpha$ activation observed in rodents cannot be directly applied for non-proliferating species such as man. Therefore, it remains unknown whether oxidised fats are able to cause PPAR $\alpha$ activation also in non-proliferating species.

The aim of the present study was to investigate whether a dietary oxidised fat, prepared by heating sunflower oil under usual deep-frying conditions $\left(180^{\circ} \mathrm{C}\right)$ for $24 \mathrm{~h}$ in a deep fryer, is able to activate PPAR $\alpha$ and to cause peroxisome proliferation in pigs. Pigs have been chosen as a model since they belong - like man - to the non-proliferating species (Yu et al. 2001; Peffer et al. 2005) and since pig liver cells show a similarity to human liver cells in the gene response to PPAR $\alpha$ agonists (Cheon et al. 2005). We focused our analyses on liver and small intestine as both tissues exhibit a high expression of PPAR $\alpha$ (Braissant et al. 1996; Lemberger et al. 1996). Moreover, both tissues play an important role in whole body lipid homeostasis, i.e. synthesis and secretion of lipoproteins rich in TAG and cholesterol (Lindsay \& Wilson, 1965; Dietschy et al. 1993). We examined the expression of various genes involved in lipid metabolism which have been already shown to be influenced by $\operatorname{PPAR} \alpha$ activation. Furthermore, in both tissues we determined gene expression of SREBP and important SREBP target genes involved in fatty acid synthesis and cholesterol uptake and synthesis.

\section{Materials and methods}

\section{Animals}

For the experiment, eighteen male 8-week-old crossbred pigs $(($ German Landrace $\times$ Large White $) \times$ Pietrain $)$ were kept in a room under controlled temperature at $23 \pm 2{ }^{\circ} \mathrm{C}$ and $55 \pm 5 \%$ relative humidity with light from 06.00 to 18.00 hours. One day before the beginning of the experimental feeding period, the pigs were weighed and randomly allocated to two groups with body weights of 12.0 (SD 1.1) $\mathrm{kg}$ in the control group and 12.2 (SD 0.9 ) $\mathrm{kg}$ in the treatment group. All experimental procedures described followed established guidelines for the care and use of laboratory animals and were approved by the local veterinary office.

\section{Diets and feeding}

Both groups of pigs received a nutritionally adequate diet for growing pigs containing (in $\mathrm{g} / \mathrm{kg}$ ) wheat (400), soyabean meal (230), wheat bran (150), barley (100), sunflower oil or test oil (90), and mineral premix including L-lysine, DL-methionine and L-threonine (30). This diet contained 14.4 MJ metabolisable energy and $185 \mathrm{~g}$ crude protein $/ \mathrm{kg}$. Diet intake was controlled, and each animal in the experiment was offered an identical amount of diet per day. During the feeding period, the amount of diet offered each day was increased continuously from 400 to $1200 \mathrm{~g}$. The pigs had free access to water via nipple drinking systems. The experimental diets were administered for $28 \mathrm{~d}$.

\section{Preparation of the test fats}

To prepare the oxidised fat, sunflower oil obtained from a local supermarket was heated at a temperature of $180^{\circ} \mathrm{C}$ for $24 \mathrm{~h}$ in a deep fryer. This treatment caused a loss of PUFA and tocopherols. The major fatty acids in the fresh and the oxidised fat, respectively, were (g/100 g total fatty acids): palmitic acid (16:0), 6.30 v. 6.70; stearic acid (18:0), $4 \cdot 0$ v. 4.2; oleic acid (18:1n-9), 22.8 v. 23.8; linoleic acid $(18: 2 n-6)$, $63.6 v$. 59.9. Other fatty acids were present only in small amounts $(<0.5 \mathrm{~g} / 100 \mathrm{~g}$ fatty acids $)$. To equalise the fatty acid composition of the fresh and the oxidised fat, the fresh fat was composed of a mixture of sunflower oil and palm oil $(93: 7, \mathrm{w} / \mathrm{w})$. To adjust dietary vitamin E concentrations, we analysed the native concentrations of tocopherols in the fresh fat and in the oxidised fats after the thermal treatment. With consideration of the native tocopherol concentrations of the dietary fats, the diets were supplemented individually with all-rac- $\alpha$-tocopheryl acetate (the biopotency of all-rac- $\alpha$-tocopheryl acetate is considered to be $67 \%$ of that of $\alpha$-tocopherol). The final vitamin $\mathrm{E}$ concentration was $620 \mathrm{mg} \alpha$-tocopherol equivalents $/ \mathrm{kg}$ in both fats. Concentrations of lipid peroxidation products were determined after the fats have been already included into the diets. Therefore, lipids of the diets were extracted by $n$-hexane and isopropanol (3:2, v/v; Hara \& Radin, 1978). Concentration of thiobarbituric acid-reactive substances (TBARS; Sidwell et al. 1954), conjugated dienes (Recknagel \& Glende, 1984), peroxide value (Deutsche Gesellschaft für Fettwissenschaft, 1994), acid value (Deutsche Gesellschaft für Fettwissenschaft, 1994) and concentration of total carbonyls (Endo et al. 2001) were determined in the extracted fat.

\section{Sample collection}

After completion of the feeding period the animals were killed under light anaesthesia. Each pig was fed its respective diet $4 \mathrm{~h}$ before being killed. After killing, blood was collected into heparinised polyethylene tubes. Plasma was obtained by centrifugation of the blood $\left(1100 \mathrm{~g}, 10 \mathrm{~min}, 4^{\circ} \mathrm{C}\right)$. Plasma lipoproteins were separated by step-wise ultracentrifugation (Mikro-Ultrazentrifuge; Sorvall Products, Bad Homburg, Germany) at $900000 \mathrm{~g}$ at $4^{\circ} \mathrm{C}$ for $1.5 \mathrm{~h}$. Plasma densities were adjusted by sodium chloride and potassium bromide and the lipoprotein fractions $\delta<1.006 \mathrm{~kg} / \mathrm{l}$ VLDL plus chylomicrons, $1.006<\delta<1.063 \mathrm{~kg} / \mathrm{l}$ LDL and $\delta>1.063 \mathrm{~kg} / \mathrm{l}$ HDL were removed by suction. The liver was dissected and weighted and samples were stored at $-80^{\circ} \mathrm{C}$ until analysis. For preparation of liver homogenate, $1 \mathrm{~g}$ liver tissue was homogenised in PBS by TissueLyser (Qiagen, Haan, Germany), centrifuged at $600 \mathrm{~g}$ for $10 \mathrm{~min}$ at $4^{\circ} \mathrm{C}$ and the supernatant was stored at $-20^{\circ} \mathrm{C}$ until analysis. For isolation of intestinal epithelial cells, the abdomen was immediately opened after killing, and a $35 \mathrm{~cm}$ intestinal segment was dissected starting at $30 \mathrm{~cm}$ distal to the pyloric sphincter, and flushed twice with ice-cold wash buffer (PBS containing 0.2 mM-phenylmethylsulphonyl fluoride and $0.5 \mathrm{~mm}$-dithiothreitol, $\mathrm{pH} \mathrm{7.4)}$. 
The isolation of porcine intestinal epithelial cells was performed by the modified distended intestinal sac technique according to Fan et al. (2004). In brief, the intestinal segments were filled with $100 \mathrm{ml}$ preincubation buffer (PBS containing 27 mM-sodium citrate, $0.2 \mathrm{~mm}$-phenylmethylsulphonyl fluoride and $0.5 \mathrm{~mm}$-dithiothreitol, $\mathrm{pH} 7 \cdot 4$ ), sealed with strings and filled intestinal segments were incubated in a saline bath $(154 \mathrm{~mm}-$ $\mathrm{NaCl}$ ) for $15 \mathrm{~min}$ at $37^{\circ} \mathrm{C}$. Afterwards, the pre-incubation buffer was discarded, and the intestinal segments were filled with isolation buffer (PBS containing $1.5 \mathrm{mM}-\mathrm{Na}_{2}$ EDTA, 0.2 mM-phenylmethylsulphonyl fluoride, $0.5 \mathrm{~mm}$-dithiothreitol and 2 mM-D-glucose, $\mathrm{pH}$ 7.4). Two major cell fractions, consisting of the upper and the crypt cell fraction, were sequentially isolated from intestinal segments through two consecutive incubations with isolation buffer at $37^{\circ} \mathrm{C}$ for 40 (upper cell fraction) and $60 \mathrm{~min}$ (crypt cell fraction), respectively. Each cell fraction was collected separately, and washed twice with ice-cold PBS. Afterwards, cells were retained by centrifugation $\left(400 \mathrm{~g}, 4 \mathrm{~min}, 4^{\circ} \mathrm{C}\right)$ and immediately frozen at $-80^{\circ} \mathrm{C}$. For further analysis, we used the crypt cell fraction as it has been shown that these cells have a 6-8-fold higher capacity of lipid synthesis than villus cells (Shakir et al. 1978).

\section{Lipid analysis}

Lipids from liver were extracted with a mixture of $n$-hexane and isopropanol ( $3: 2$, v/v; Hara $\&$ Radin, 1978). For determination of the concentrations of lipids in liver, aliquots of the lipid extracts were dried and the lipids were dissolved using Triton X-100 (De Hoff et al. 1978). Concentrations of TAG and cholesterol in plasma and lipoproteins and those of liver were determined using enzymatic reagent kits (cat. no. 113009990314 for cholesterol and cat. no. 157609990314 for TAG; Ecoline $\mathrm{S}^{+}$, DiaSys, Holzheim, Germany).

\section{Preparation of liver microsomal and cytosolic fractions}

Liver ( $1 \mathrm{~g}$ ) was homogenised in $10 \mathrm{ml} \mathrm{0.1} \mathrm{M-phosphate} \mathrm{buffer,}$ $\mathrm{pH} 7 \cdot 4$, containing $0.25 \mathrm{M}$-sucrose using a Potter-Elvehjem homogeniser. Homogenates were centrifuged at $1000 \mathrm{~g}$ for $10 \mathrm{~min}$ at $4^{\circ} \mathrm{C}$, and the supernatant was centrifuged at $15000 \mathrm{~g}$ for a further $15 \mathrm{~min}$. The microsomal pellet was obtained by centrifugation of the $15000 \mathrm{~g}$ supernatant at $105000 \mathrm{~g}$ for $60 \mathrm{~min}$. The resulting cytosolic fraction in the supernatant was separated, microsomal pellets were resuspended in the homogenisation buffer and all samples were stored at $-20^{\circ} \mathrm{C}$ for further analysis. The protein concentrations of cytosolic and microsomal fractions were determined with the BCA reagent according to the protocol of the supplier (Interchim, Montelucon, France) using bovine serum albumin as standard.

\section{$R T-P C R$ analysis}

Total RNA from liver tissue and enterocytes, respectively, was isolated by the TissueLyser (Qiagen) using Trizol reagent (Invitrogen, Karlsruhe, Germany) according to the manufacturer's protocol. RNA concentration and purity were estimated from the optical density at 260 and $280 \mathrm{~nm}$ (SpectraFluor Plus; Tecan, Crailsheim, Germany). The quality of all RNA samples was furthermore assessed by agarose gel electrophoresis.
Total RNA $(1.2 \mu \mathrm{g})$ was used for cDNA synthesis as described previously (König \& Eder, 2006). The mRNA concentration of genes was measured by real-time detection PCR using SYBR $^{\circledR}$ Green I and the Rotor Gene 2000 system (Corbett Research, Mortlake, Australia). Real-time detection PCR was performed with $1.25 \mathrm{U}$ Taq DNA polymerase, $500 \mu \mathrm{M}$ dNTP and 26.7 pmol of the specific primers. For determination of mRNA concentration a threshold cycle $\left(C_{\mathrm{t}}\right)$ and amplification efficiency was obtained from each amplification curve using the software RotorGene 4.6 (Corbett Research). Calculation of the relative mRNA concentration was made using the $\Delta \Delta C_{\mathrm{t}}$ method as previously described (Pfaffl, 2001). The housekeeping gene glyceraldehyde-3-phosphate dehydrogenase was used for normalisation. The PCR primers used for real-time RT-PCR were obtained from Operon (Köln, Germany) and Roth (Karlsruhe, Germany), respectively, and are listed in Table 1.

\section{Enzyme assays}

Superoxide dismutase (SOD) activity in liver cytosol was determined according to the method of Marklund \& Marklund (1974) with pyrogallol as the substrate. One unit of SOD activity is defined as the amount of enzyme required to inhibit the autoxidation of pyrogallol by $50 \%$. The activity of glutathione peroxidase in liver cytosol was determined with $t$-butyl hydroperoxide as substrate according to the method of Paglia $\&$ Valentine (1967). One unit of glutathione peroxidase activity is defined as $1 \mu \mathrm{mol}$ reduced $\beta$-nicotinamide adenine dinucleotide phosphate oxidised/min. The activity of glutathione $S$-transferase was determined using 1-chloro-2,4-dinitrobenzene as substrate as described by Habig et al. (1974). One unit of glutathione $S$-transferase is defined as one nmol substrate consumed/min. Catalase activity in liver homogenate was determined using $\mathrm{H}_{2} \mathrm{O}_{2}$ as substrate according to the method of Aebi (1986). One unit of catalase activity is defined as the amount consuming $1 \mathrm{mmol}_{2} \mathrm{O}_{2} / \mathrm{min}$.

\section{Determination of conjugated dienes, thiobarbituric acid-reactive substances and $\alpha$-tocopherol}

Lipids from liver were extracted using a mixture of $n$-hexane and isopropanol (3:2, v/v; Hara \& Radin, 1978). After drying the lipid extracts, $1 \mathrm{mg}$ extract was dissolved in $1 \mathrm{ml} n$-hexane. The concentrations of conjugated dienes were calculated by using the molar extinction coefficient for conjugated dienes at $234 \mathrm{~nm}(\epsilon=29500 \mathrm{~mol} / \mathrm{cm})$. The concentrations of TBARS were measured in liver homogenates as described (Brandsch et al. 2002). The concentration of $\alpha$-tocopherol in liver tissue was determined by HPLC (Brandsch et al. 2002).

\section{Determination of $\mathrm{H}_{2} \mathrm{O}_{2}$}

To determine the $\mathrm{H}_{2} \mathrm{O}_{2}$ content in liver homogenates, the method for cell culture systems described by Royall \& Ischiropoulos (1993) was modified, using dihydrorhodamine 123 as substrate. Homogenates were incubated with $27.5 \mu \mathrm{M}$-dihydrorhodamine 123 for $1 \mathrm{~h}$ at $37^{\circ} \mathrm{C}$ in a final volume of $400 \mu \mathrm{l}$. After incubation, the fluorescence of rhodamine 123, the oxidation product of dihydrorhodamine 123, was measured (excitation wavelength $485 \mathrm{~nm}$, emission wavelength $538 \mathrm{~nm}$ ). 
Table 1. Characteristics of the specific primers used for RT-PCR analysis

\begin{tabular}{|c|c|c|c|c|c|}
\hline Gene & Forward primer (from $5^{\prime}$ to $3^{\prime}$ ) & Reverse primer (from $5^{\prime}$ to $3^{\prime}$ ) & $\mathrm{bp}$ & Annealing temp. $\left({ }^{\circ} \mathrm{C}\right)$ & NCBI GenBank \\
\hline ACC & CTCCAGGACAGCACAGATCA & GCCGAAACATCTCTGGGATA & 170 & 60 & AF175308 \\
\hline ACO & CTCGCAGACCCAGATGAAAT & TCCAAGCCTCGAAGATGAGT & 218 & 60 & AF185048 \\
\hline apo CIII & GACACCTCCCTTCTGGACAA & TCCCAGAAGTCGGTGAACTT & 185 & 60 & NM_001002801 \\
\hline CPT-1 & GCATTTGTCCCATCTTTCGT & GCACTGGTCCTTCTGGGATA & 198 & 60 & AF288789 \\
\hline CYP7 & TATAGGGCACGATGCACAGA & ACCTGACCAGTTCCGAGATG & 200 & 60 & NM_001005352 \\
\hline FAS & GAACACGGCCTAGAAGTGGA & ATCTGGATCCTGCAGATGG & 199 & 62 & NM_213839 \\
\hline FATP & GGTTCCAGCCTGTTGAATGT & AACAAAACCTTGGTGCTTGG & 275 & 60 & DQ192231 \\
\hline FDPS & GAAAGGCAGGATTTCATCCA & AGAAGGCTTGGAGCAGTTCA & 259 & 60 & AY609787 \\
\hline GAPDH & AGGGGCTCTCCAGAACATCATCC & TCGCGTGCTCTTGCTGGGGTTGG & 446 & 60 & AF017079 \\
\hline Glutathione peroxidase & CAAGAATGGGGAGATCCTGA & GATAAACTTGGGGTCGGTCA & 190 & 60 & NM_214201 \\
\hline Glutathione $S$-transferase & TTTTTTGCCAACCCAGAAGAC & GGGGTGTCAAATACGCAATC & 246 & 60 & NM_214300 \\
\hline HMG-CoA-R & GGTCAGGATGCGGCACAGAACG & GCCCCACGGTCCCGATCTCTATG & 127 & 65 & S79678 \\
\hline I-FABP & TACAGCCTCGCAGACGGAACTG & TGCTTGATGAGGAGAGGAAAACAG & 276 & 59 & AY960624 \\
\hline Insig-1 & AGAGGGAGTGGGCCAGTGTGATGC & ACGGGAGCCAGGAGCGGATGTAG & 276 & 65 & AY336601 \\
\hline Insig-2 & AAATCACGCCAGCGCTAAAGTG & TCCTACTCCAAGGCCAAAACCAC & 127 & 60 & AY585269 \\
\hline LDL receptor & AGAACTGGCGGCTGAAGAGCATC & GAGGGGTAGGTGTAGCCGTCCTG & 115 & 60 & AF118147 \\
\hline L-FABP & TTCGGTGCATGTCTAAGCTG & TGAGAGGGAGAGGATGAGGA & 200 & 60 & DQ182323 \\
\hline mAAT & TATGTCACCGTGCAGACCAT & СТССТTCСАСТGСTCAGGAC & 309 & 60 & M11732 \\
\hline mHMG-CoA-S & GGACCAAACAGACCTGGAGA & ATGGTCTCAGTGCCCACTTC & 198 & 62 & U90884 \\
\hline MTP & CAGGACGGCAAAGAAAGAAGG & ATGGGAAGCAAAACCACAAGG & 199 & 60 & AY217034 \\
\hline NPC1 & ACGCGGTATCTTTGGTCAAC & AGTGGCTCCCAGCAAGACTA & 266 & 60 & AF169635 \\
\hline NPC2 & GGAGGGGAGGAGAAATCAAG & ATTCGGGTCTTGTCTGGTTG & 267 & 60 & NM_214206 \\
\hline PPAR $\alpha$ & CAGCCTCCAGCCCCTCGTC & GCGGTCTCGGCATCTTCTAGG & 382 & 58 & DQ437887 \\
\hline SCD & ACGTTGTGCCAGTGAGTCAG & GTCTTGGCCTCTTGTGCTTC & 206 & 62 & NM_213781 \\
\hline SOD & TCCATGTCCATCAGTTTGGA & CTGCCCAAGTCATCTGGTTT & 250 & 60 & AF396674 \\
\hline SREBP-1 & ССТСТGТСТСТССТGСАСС & ACAAAGAGAAGCGCCAAGAA & 213 & 62 & NM_214157 \\
\hline SREBP-2 & CGCTCGCGAATCCTGCTGTG & GGTGCGGGTCCGTGTCGTG & 103 & 65 & DQ020476 \\
\hline
\end{tabular}

ACC, acetyl-CoA carboxylase; ACO, acyl-CoA oxidase; CPT-1, carnitine palmitoyltransferase-1; CYP7, cholesterol $7 \alpha$-hydroxylase; FAS, fatty acid synthase; FATP, fatty acid transport protein; FDPS, farnesyl diphosphate synthase; GAPDH, glyceraldehyde-3-phosphate dehydrogenase; HMG-CoA-R, 3-hydroxy-3-methylglutaryl-CoA reductase; I-FABP, intestinal fatty acid binding protein; Insig, insulin-induced gene; L-FABP, liver fatty acid binding protein mAAT, mitochondrial aspartate aminotransferase; mHMG-CoA-S, mitochondrial 3-hydroxy-3-methylglutaryl-CoA synthase; MTP, microsomal TAG transfer protein; NPC, Niemann-Pick type C; SCD, stearoyl-CoA desaturase; SOD, superoxide dismutase; SREBP, sterol regulatory element-binding protein. 
As previously shown by Walrand et al. (2003), dihydrorhodamine 123 is specifically oxidised by $\mathrm{H}_{2} \mathrm{O}_{2}$.

\section{Determination of 3-hydroxybutyrate}

Concentration of 3-hydroxybutyrate in plasma was determined using an enzymatic assay (cat. no. 10907979035; R-Biopharm AG, Darmstadt, Germany).

\section{Transmission electron microscopy}

Liver tissues were fixed in $3 \%$ sodium cacodylate-buffered glutaraldehyde $(\mathrm{pH} 7.2)$ and post-fixed with $1 \%$ osmium tetroxide. After washing three times, probes were dehydrated in an ethanol series and embedded in Spurr's epoxy resin. For observations with an EM 900 transmission electron microscope (Carl Zeiss SMT, Oberkochen, Germany), ultrathin sections $(80 \mathrm{~nm})$ were mounted on copper grids. Catalase is known to be located in peroxisomes specifically and was marked for a better visualisation of peroxisomes. For immunohistochemistry, ultrathin sections were blocked for $30 \mathrm{~min}$ with $1 \%$ bovine serum albumin and $0.1 \%$ Tween in PBS and incubated overnight with sheep polyclonal anti-catalase serum (1 : 50; Biotrend, Köln, Germany). For detection of primary antibody, sections were incubated for $1 \mathrm{~h}$ with a goldmarked donkey-anti-sheep antibody (1:25; Biotrend) and finally stained with uranyl acetate/lead citrate. Peroxisomes were counted in 1000 different prints per liver sample for each animal with a magnification of $12000 \times$.

\section{Statistics}

The results were analysed using Minitab (State College, PA, USA) statistical software (release 13). Statistical significance of differences of the mean values of the two groups of pigs was evaluated using Student's $t$ test. Mean values were considered significantly different for $P<0 \cdot 05$.

\section{Results}

Fatty acid composition and concentration of lipid peroxidation products in the dietary fats

Palmitic, stearic, oleic and linoleic acid were the major fatty acids in the dietary fats. The sum of these fatty acids accounted for about $95 \mathrm{~g} / 100 \mathrm{~g}$ total fatty acids in the fats (Table 2). Amounts of stearic, oleic and linoleic acid were nearly identical in both fats; the amount of stearic acid was slightly higher in the fresh fat than in the oxidised fat. Peroxide value, acid value and concentration of conjugated dienes were 4-5-fold higher in the oxidised than in the fresh fat included in the diet (Table 2). The concentration of total carbonyls was 10-fold higher and that of TBARS was 30 -fold higher in the oxidised than in the fresh fat (Table 2).

\section{Body weights, antioxidant status and concentrations of lipid peroxidation products in the liver}

Body weights of the pigs at the end of the experiment on day 28 did not differ between the two groups (25.6 (SD 1.4) v. 26.0 (SD 1.5) $\mathrm{kg}$ in pigs fed the oxidised fat $v$. pigs fed the fresh fat;
Table 2. Major fatty acids and concentrations of some lipid peroxidation products in the fresh and the oxidised fat after inclusion into the diet

\begin{tabular}{lcc}
\hline & Fresh fat & Oxidised fat \\
\hline Major fatty acids $(\mathrm{g} / 100 \mathrm{~g}$ fatty acids) & & \\
$16: 0$ & $9 \cdot 0$ & $6 \cdot 7$ \\
$18: 0$ & $4 \cdot 1$ & $4 \cdot 2$ \\
$18: 1 n-9$ & $23 \cdot 7$ & $23 \cdot 8$ \\
$18: 2 n-6$ & $59 \cdot 8$ & $59 \cdot 9$ \\
Peroxidation products & & \\
Conjugated dienes $(\mathrm{mmol} / \mathrm{kg})$ & $22 \cdot 7$ & $89 \cdot 1$ \\
TBARS $(\mu \mathrm{mol} / \mathrm{kg})$ & 9 & 271 \\
Peroxide value $\left(\mathrm{mEq} \mathrm{O}_{2} / \mathrm{kg}\right)$ & $2 \cdot 5$ & $10 \cdot 0$ \\
Acid value $(\mathrm{g} \mathrm{KOH} / \mathrm{kg})$ & 1.6 & $8 \cdot 0$ \\
Total carbonyls $(\mathrm{mmol} / \mathrm{kg})$ & $2 \cdot 5$ & 24.5 \\
\hline
\end{tabular}

TBARS, thiobarbituric acid-reactive substances.

nine pigs per group). Pigs fed the oxidised fat had a higher mRNA concentration and a higher activity of SOD and a lower activity of microsomal glutathione $S$-transferase in the liver than pigs fed the fresh fat $(P<0.05$; Table 3$)$. Activities of glutathione peroxidase and cytosolic glutathione $S$-transferase as well as mRNA concentrations of these enzymes in the liver did not differ between both groups of pigs (Table 3 ). Concentrations of total, reduced and oxidised glutathione in the liver also did not differ between the two groups of pigs whereas the concentration of $\alpha$-tocopherol was lower in pigs fed the oxidised fat than in pigs fed the fresh fat $(P<0.05$; Table 3). Concentration of TBARS in the liver did not differ between the two groups of pigs whereas the concentration of conjugated dienes was slightly but significantly higher in pigs fed the oxidised fat than in pigs fed the fresh fat $(P<0 \cdot 05$; Table 3$)$.

\section{Indices of peroxisome proliferation}

Liver weights of the pigs were not different between the two groups but pigs fed the oxidised fat had a higher peroxisome count and a higher activity of catalase in the liver than pigs fed the fresh fat $(P<0.05$; Table 4$)$. Relative mRNA concentration of acyl-CoA oxidase (ACO), a peroxisomal enzyme, in the liver, was $34 \%$ higher in pigs fed the oxidised fat than in control animals $(P=0.062$; Table 4$)$. The concentration of $\mathrm{H}_{2} \mathrm{O}_{2}$ which is mainly released from peroxisomal oxidases was not different between the two groups of pigs (Table 4).

\section{mRNA concentrations of genes in liver and intestine}

In liver, mRNA concentrations of PPAR $\alpha$ and genes involved in fatty acid transport and oxidation [liver fatty acid binding protein (L-FABP), carnitine palmitoyltransferase-1 (CPT-1)], fatty acid and cholesterol synthesis [SREBP-1 and -2, insulin-induced gene-1 and -2, fatty acid synthase, acetyl-CoA carboxylase (ACC), stearoyl-CoA desaturase (SCD), 3-hydroxy3-methylglutaryl-CoA reductase (HMG-CoA-R)], cholesterol uptake (LDL receptor), bile acid synthesis [cholesterol $7 \alpha-$ hydroxylase (CYP7)], lipoprotein assembly and secretion [microsomal TAG transfer protein (MTP)], inhibition of lipoprotein lipase (apo CIII) and ketogenesis [mitochondrial 3-hydroxy-3-methylglutaryl-CoA synthase (mHMG-CoA-S)] 
Table 3. mRNA concentrations and activities of antioxidant enzymes and concentrations of antioxidants and lipid peroxidation products in livers of pigs fed a diet with a fresh fat or an oxidised fat

(Mean values and standard deviations)

\begin{tabular}{|c|c|c|c|c|}
\hline & \multicolumn{2}{|c|}{ Fresh fat $(n 9)$} & \multicolumn{2}{|c|}{ Oxidised fat $(n 9)$} \\
\hline & Mean & SD & Mean & SD \\
\hline \multicolumn{5}{|l|}{ Superoxide dismutase } \\
\hline mRNA concentration (relative) & 1.00 & 0.22 & $1 \cdot 24^{*}$ & 0.14 \\
\hline Activity (U/mg protein) & $42 \cdot 7$ & 8.4 & $58 \cdot 8^{*}$ & $6 \cdot 0$ \\
\hline Glutathione $S$-transferase & 202 & 42 & $144^{*}$ & 13 \\
\hline mRNA concentration (relative) & 1.00 & 0.31 & 1.27 & 0.23 \\
\hline Activity in microsomes ( $\mathrm{U} / \mathrm{mg}$ protein) & 202 & 42 & $144^{*}$ & 13 \\
\hline Activity in cytosol (U/mg protein) & 760 & 262 & 761 & 186 \\
\hline \multicolumn{5}{|l|}{ Glutathione peroxidase } \\
\hline mRNA concentration (relative) & 1.00 & 0.13 & $1 \cdot 14$ & 0.22 \\
\hline Activity (U/mg protein) & 4.72 & 0.77 & $5 \cdot 14$ & 0.75 \\
\hline Glutathione, total (nmol/mg) & $2 \cdot 13$ & 0.51 & $2 \cdot 17$ & 0.37 \\
\hline Glutathione, reduced $(\mathrm{nmol} / \mathrm{mg})$ & $1 \cdot 70$ & 0.50 & 1.84 & 0.55 \\
\hline Glutathione, oxidised $(\mathrm{nmol} / \mathrm{mg})$ & 0.21 & 0.12 & 0.17 & $0 \cdot 10$ \\
\hline$\alpha$-Tocopherol $(\mathrm{nmol} / \mathrm{g})$ & 14.5 & 2.5 & $11.9^{*}$ & 1.8 \\
\hline Conjugated dienes ( $\mu \mathrm{mol} / \mathrm{mg}$ protein) & 16 & 1 & $18^{\star}$ & 3 \\
\hline TBARS $(\mathrm{mmol} / \mathrm{g})$ & $7 \cdot 2$ & 1.6 & $7 \cdot 3$ & $2 \cdot 8$ \\
\hline
\end{tabular}

TBARS, thiobarbituric acid-reactive substances.

Mean values were significantly different from those of the fresh fat group: ${ }^{\star} P<0.05$.

were determined (Fig. 1). Pigs fed the oxidised fat had significantly higher mRNA concentrations of mHMG-CoA-S, a classical PPAR $\alpha$ target gene, SREBP-1 and its target genes ACC and SCD, and SREBP-2 and its target genes HMG-CoA-R and LDL receptor than control pigs fed the fresh fat $(P<0 \cdot 05)$. mRNA concentration of CYP7 was lower in pigs fed the oxidised fat than in pigs fed the fresh fat $(P<0 \cdot 05)$. mRNA concentrations of CPT- 1 and MTP, two other PPAR $\alpha$ target genes, tended to be increased in pigs fed the oxidised fat ( $P=0.074$ and $P=0.065$, respectively) compared to pigs fed the fresh fat whereas mRNA concentrations of PPAR $\alpha$, L-FABP, apo CIII, insulin-induced gene-1 and -2, and fatty acid synthase were not different between pigs fed the fresh fat and those fed the oxidised fat (Fig. 1).

In enterocytes, relative mRNA concentrations of PPAR $\alpha$ and of proteins involved in fatty acid uptake (L-FABP, intestinal fatty acid binding protein, fatty acid transport protein, mitochondrial aspartate aminotransferase), fatty acid oxidation (ACO, CPT-1), intracellular trafficking of cholesterol (Niemann-Pick type $\mathrm{C} 1$ and 2) and fatty acid synthesis (SREBP-1, fatty acid synthase) were not different between pigs fed the oxidised fat and those fed the fresh fat (Fig. 2).
However, mRNA concentration of SREBP-2 and its target genes HMG-CoA-R and LDL receptor, involved in cholesterol synthesis and uptake, were higher in pigs fed the oxidised fat than in pigs fed the fresh fat $(P<0 \cdot 05$; Fig. 2$)$. mRNA concentration of farnesyl diphosphate synthase did not differ between the two groups of pigs (Fig. 2).

\section{Concentrations of TAG and cholesterol in liver, plasma and lipoproteins}

Concentrations of TAG in liver, plasma and TAG-rich lipoproteins did not differ between pigs fed the fresh fat and those fed the oxidised fat. Concentrations in pigs fed the oxidised fat $v$. pigs fed the fresh were (nine pigs per group): liver, 88 (SD 20) v. 91 (SD 19) $\mu \mathrm{mol} / \mathrm{g}$; plasma, 0.96 (SD 0.26) $v$. 1.09 (SD 0.17) $\mathrm{mmol} / \mathrm{l}$; chylomicrons + VLDL, 0.80 (SD $0.25)$ v. 0.93 (SD 0.16$) \mathrm{mmol} / \mathrm{l}$. Concentrations of cholesterol in liver, plasma, LDL and HDL were also not different between the two groups of pigs. Concentrations in pigs fed the oxidised fat $v$. pigs fed the fresh were: liver, 73 (SD 14) v. 69 (SD 10) $\mu \mathrm{mol} / \mathrm{g}$; plasma, 2.63 (SD 0.32)

Table 4. Indices of peroxisome proliferation in livers of pigs fed a diet with a fresh fat or an oxidised fat (Mean values and standard deviations)

\begin{tabular}{lccccc}
\hline & \multicolumn{2}{c}{ Fresh fat $(n 9)$} & & \multicolumn{2}{c}{ Oxidised fat $(n 9)$} \\
\cline { 2 - 3 } \cline { 5 - 6 } & Mean & SD & & Mean & SD \\
\hline Liver weight (g) & 673 & 63 & & 700 & 64 \\
Peroxisome count (number/print) & 366 & 67 & & $515^{*}$ & 91 \\
Acyl-CoA oxidase mRNA concentration (relative) & 1.00 & 0.33 & & $1.34 \dagger$ & 0.37 \\
Catalase (U/mg protein) & 0.75 & 0.14 & & $0.89^{*}$ & 0.13 \\
$\mathrm{H}_{2} \mathrm{O}_{2}$ (fluorescence/g liver) & 29372 & 12343 & & 29437 & 8361 \\
\hline
\end{tabular}

Mean values were significantly different from those of the fresh fat group: $\dagger P<0.1 ;{ }^{\star} P<0.05$. 


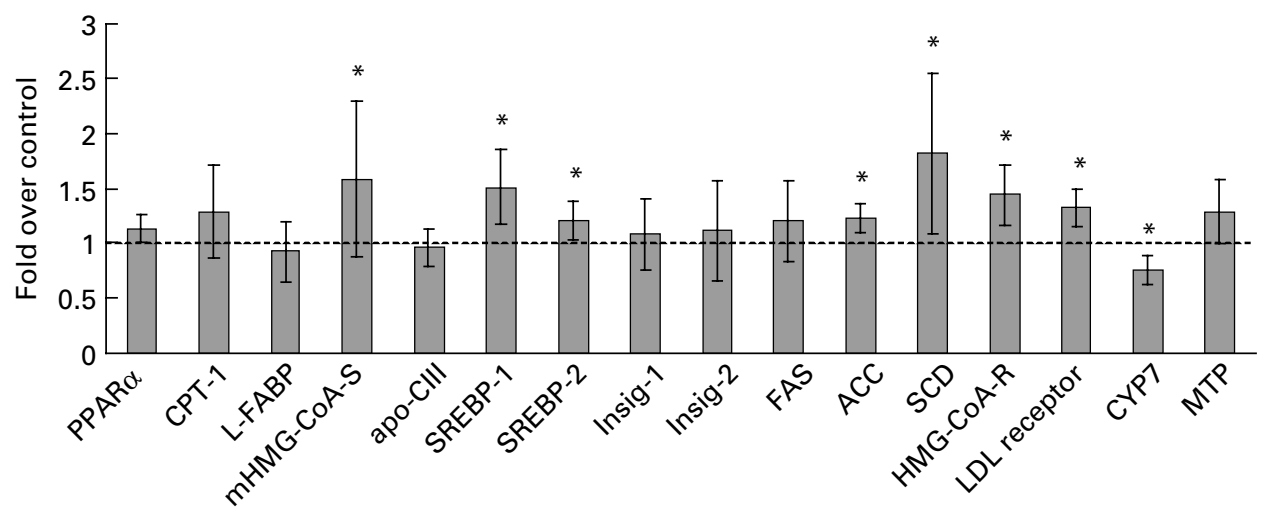

Fig. 1. Relative mRNA concentrations (--- represents 1.00) of various genes involved in hepatic lipid metabolism in enterocytes of pigs fed a diet with a fresh fat or an oxidised fat. Values were determined by real-time detection RT-PCR using the mRNA concentration of glyceraldehyde-3-phosphate dehydrogenase for normalisation Values are means with their standard deviations depicted by vertical bars $(n 9)$ obtained for the pigs fed the oxidised fat relative to the values of the control group fed fresh fat. ACC, acetyl-CoA carboxylase; CPT-1, carnitine palmitoyltransferase-1; CYP7, cholesterol $7 \alpha$-hydroxylase; FAS, fatty acid synthase; HMG-CoA-R, 3-hydroxy-3-methylglutaryl-CoA reductase; Insig, insulin-induced gene; L-FABP, liver fatty acid binding protein; mHMG-CoA-S, mitochondrial 3-hydroxy-3-methylglutaryl-CoA synthase; MTP, microsomal TAG transfer protein; SCD, stearoyl-CoA desaturase; SREBP, sterol regulatory element-binding protein. Mean values were significantly different from those of the fresh fat group: ${ }^{*} P 0.05$.

v. $2 \cdot 83(\mathrm{SD} 0 \cdot 22) \mathrm{mmol} / \mathrm{l} ; \mathrm{LDL}, 0.96(\mathrm{SD} 0 \cdot 16)$ v. $0.97(\mathrm{SD} \mathrm{0} \cdot 15)$ $\mathrm{mmol} / \mathrm{l}$; HDL, 1.02 (SD 0.18) v. 1.13 (SD 0.11) $\mathrm{mmol} / \mathrm{l}$.

\section{Concentration of 3-hydroxybutyrate in plasma}

Pigs fed the oxidised fat had a higher concentration of 3-hydroxybutyrate in plasma than pigs fed the fresh fat (1.23 (SD 0.58) v. 0.52 (SD 0.27) mmol/l; $P<0.05$ ).

\section{Discussion}

In the present study, pigs were fed a diet containing an oxidised fat prepared under usual deep-frying conditions. The relatively low concentrations of lipid peroxidation products (conjugated dienes, TBARS, peroxides and carbonyls) in the oxidised fat indicate that this fat was mildly oxidised. Concentrations of peroxidation products in this fat were indeed even lower than in soyabean oil or hydrogenated animal-vegetable oil blends used for frying of potatoes at $190^{\circ} \mathrm{C}$ over a period of $24 \mathrm{~h}$ (Frankel, 1998). The reason for the relatively low degree of oxidation is that we did not add foodstuffs to be fried during the preparation of the oil as we wanted to avoid contamination of the oil with food ingredients. It is well known that ingredients of foodstuffs, i.e. metal ions, enhance the lipid peroxidation process during frying of fats (Kubow, 1992). The concentration of conjugated dienes which include the potent PPAR $\alpha$ activators hydroxy- and hydroperoxy fatty acids (Delerive et al. 2000; König \& Eder, 2006) was approximately four times higher in the oxidised fat than in the fresh fat. The finding of an increased activity of SOD and a slightly elevated concentration of conjugated dienes, together with the observation of a slightly reduced concentration of $\alpha$-tocopherol, indicates that the oxidised fat produced oxidative stress in the liver of the pigs. It has been demonstrated that under

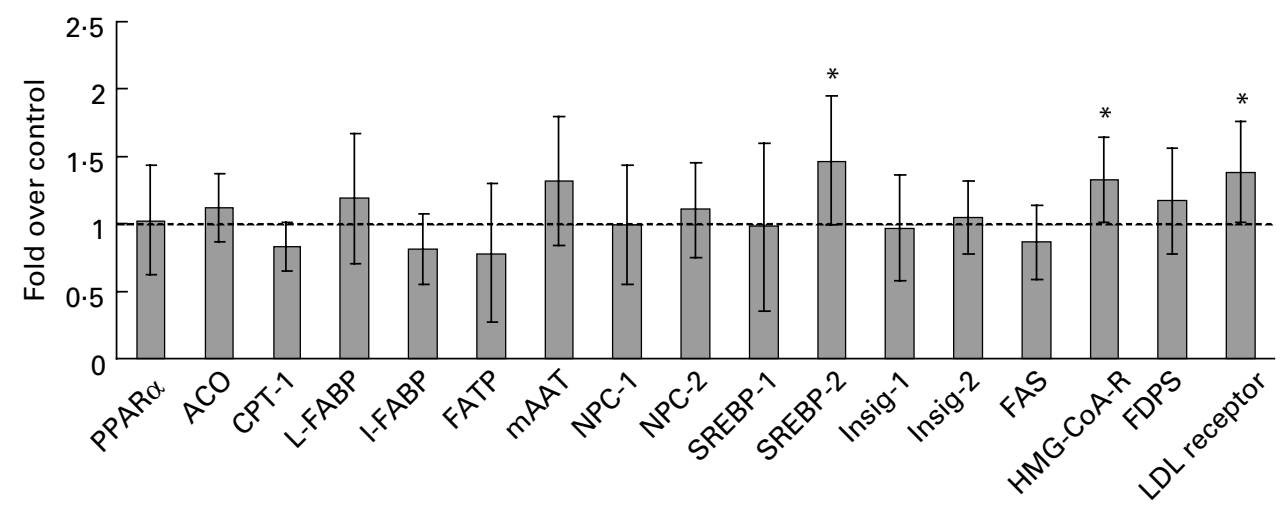

Fig. 2. Relative mRNA concentrations (--- represents 1.00) of various genes involved in intestinal lipid metabolism in livers of pigs fed a diet with a fresh fat or an oxidised fat. Values were determined by real-time detection RT-PCR using the mRNA concentration of glyceraldehyde-3-phosphate dehydrogenase for normalisation. Values are means with their standard deviations depicted by vertical bars $(n 9)$ obtained for the pigs fed the oxidised fat relative to the values of the control group fed fresh fat. ACO, acyl-CoA oxidase; CPT-1, carnitine palmitoyltransferase-1; FAS, fatty acid synthase; FATP, fatty acid transport protein; FDPS, farnesyl diphosphate synthase; HMG-CoA-R, 3-hydroxy-3-methylglutaryl-CoA reductase; I-FABP, intestinal fatty acid binding protein; Insig, insulin-induced gene; L-FABP, liver fatty acid binding protein; mAAT, mitochondrial aspartate aminotransferase; NPC, Niemann-Pick type C; SREBP, sterol regulatory element-binding protein. Mean values were significantly different from those of the fresh fat group: ${ }^{*} P<0.05$. 
oxidative stress, expression of SOD is stimulated and concentration of $\alpha$-tocopherol is reduced due to an enhanced consumption (Liu \& Huang, 1995; Ruiz-Gutierrez et al. 1999; Atalay et al. 2000). However, the oxidative stress produced by the oxidised fat was very moderate as concentrations of TBARS and glutathione remained completely unchanged. In rodents treated with PPAR $\alpha$ agonists such as fibrates or WY-14,643, production of $\mathrm{H}_{2} \mathrm{O}_{2}$ is largely increased due to a strong up-regulation of peroxisomal oxidases, and this causes oxidative stress and contributes to hepatocarcinogenesis in these species (Peters et al. 2005). In the present study, feeding the oxidised fat did not increase the concentration of $\mathrm{H}_{2} \mathrm{O}_{2}$ in the liver. This was probably due to two reasons: first, there was only a slight increase in the mRNA concentration of ACO, one of the enzymes producing $\mathrm{H}_{2} \mathrm{O}_{2}$; second, activity of catalase, the key enzyme of decomposition of $\mathrm{H}_{2} \mathrm{O}_{2}$ in peroxisomes was increased. Therefore, generation of $\mathrm{H}_{2} \mathrm{O}_{2}$ did not contribute to oxidative stress in animals treated with oxidised fat. The reason for the moderate oxidative stress may be that a part of the dietary lipid peroxidation products is absorbed in the intestine and reaches the liver via lipoproteins (Staprans et al. 2005). Production of oxidative stress by intake of strongly oxidised fats has been shown several times in rodents (Yoshida \& Kajimoto, 1989; Liu \& Huang, 1996; Liu \& Lee, 1998; Ammouche et al. 2002; Eder et al. 2004; Keller et al. 2004a, b). The present study shows for the first time that even a mildly oxidised fat, as used in human nutrition, can induce moderate oxidative stress in pigs as a non-proliferating species.

To find out whether the mildly oxidised fat caused activation of PPAR $\alpha$ in the liver of pigs, we determined mRNA concentrations of the classical PPAR $\alpha$ target genes ACO, CPT- 1 and mHMG-CoA-S as well as peroxisome count, activity of catalase and plasma concentration of 3-hydroxybutyrate. Recent studies in pigs have shown that activation of $\operatorname{PPAR} \alpha$ in pigs, by either treatment with clofibrate or by fasting, leads to an increased expression of these PPAR $\alpha$ target genes, and in turn stimulates mitochondrial and peroxisomal $\beta$-oxidation and ketogenesis (Yu et al. 2001; Peffer et al. 2005; Cheon et al. 2005). The finding of an increased peroxisome count together with increased activity of catalase, a peroxisomal enzyme, a significantly increased mRNA concentration of mHMG-CoA-S and an increased plasma concentration of 3-hydroxybutyrate strongly indicate that the oxidised fat caused PPAR $\alpha$ activation in the liver of the pigs. The finding that mRNA concentrations of ACO and CPT-1, two other classical PPAR $\alpha$ target genes were also increased by 34 and $29 \%$, although not significantly different to control, supports the assumption that the oxidised fat induced hepatic PPAR $\alpha$ activation in the pigs. It has been shown that these two enzymes are only moderately up-regulated in pig liver by PPAR $\alpha$ agonists. For instance, in pigs treated with clofibrate, a strong PPAR $\alpha$ agonist, hepatic gene expression of CPT-1 and ACO was only 1.89- and 1.42-fold, respectively, increased over control while gene expression of $\mathrm{mHMG}-\mathrm{CoA}-\mathrm{S}$ was increased 3·32-fold (Cheon et al. 2005). This presents an explanation for the observations that mHMG-CoA-S was significantly increased in pigs treated with oxidised fat and that ACO and CPT-1 were only slightly increased. The finding that mRNA concentration of MTP, a gene recently shown to be up-regulated by PPAR $\alpha$ activation (Ameen et al. 2005), tended to be increased in the liver of pigs fed the oxidised fat also indicates that the oxidised fat caused PPAR $\alpha$ activation in the liver. Recently, studies in rats have already shown that oxidised fats are able to activate PPAR $\alpha$ in the liver (Huang et al. 1988; Chao et al. 2001; Sülzle et al. 2004). In these rat studies, up-regulation of PPAR $\alpha$ target genes in the liver was much stronger than in pigs of the present study. This may have two different reasons: first, most PPAR $\alpha$ target genes respond stronger to PPAR $\alpha$ activation in rats than in non-proliferating species such as pigs or man; second, fats used in the rat studies were more strongly oxidised than the mildly oxidised fat used in the present study. The present study shows for the first time that even a mildly oxidised fat causes activation of PPAR $\alpha$ in pigs which are, as man, less sensitive to PPAR $\alpha$ agonists than rodents.

To study whether the oxidised fat caused PPAR $\alpha$ activation in small intestine, we considered in addition to the classical PPAR $\alpha$ target genes ACO and CPT-1, several genes involved in fatty acid transport (L-FABP, intestinal fatty acid binding protein, fatty acid transport protein and mitochondrial aspartate aminotransferase) and cholesterol trafficking (NiemannPick type $\mathrm{C} 1$ and 2) in intestinal tissue. All these genes have been shown to be up-regulated by PPAR $\alpha$ activation (Darimont et al. 1998; Motojima et al. 1998; Mochizuki et al. 2001; Chinetti-Gbaguidi et al. 2005). The finding that none of these genes was up-regulated in cells of small intestine indicates that oxidised fat caused no or even weak PPAR $\alpha$ activation and does not influence intestinal fatty acid transport and cholesterol trafficking.

Synthesis of lipids in mammalian cells is controlled by a network involving the action of insulin-induced genes and SREBP, and it has been recently shown in several studies that this network is influenced by PPAR $\alpha$ activation (Guo et al. 2001; Patel et al. 2001; Knight et al. 2005; König et al. 2006). The present study shows that feeding a mildly oxidised fat increased the mRNA concentration of SREBP-1 and its target genes ACC and SCD, two key enzymes of de novo fatty acid synthesis, in the liver. These alterations may be caused by activation of PPAR $\alpha$ in the liver. Knight et al. (2005) found that treatment with WY 14,643, a synthetic PPAR $\alpha$ agonist, causes a strong up-regulation of enzymes involved in hepatic fatty acid synthesis and stimulates fatty acid synthesis in wild-type mice but not in PPAR $\alpha$ null mice. Knight et al. (2005) suggest that up-regulation of hepatic fatty acid synthesis is a compensatory response on the increased fatty acid oxidation to maintain a constant cellular TAG level. The finding that TAG levels in liver and plasma were not reduced in pigs fed the oxidised fat compared to control pigs indeed suggests that an increased $\beta$-oxidation of fatty acids was compensated by an increased fatty acid synthesis. As there is no evidence for a direct action of PPAR $\alpha$ on the promoter regions of SREBP-1 and ACC genes, it is likely that the increased mRNA concentrations of these genes are an indirect result of PPAR $\alpha$ activation. In contrast, SCD is not only dependent on SREBP-1 but has also a PPAR response element in its promoter (Miller \& Ntambi, 1996). Therefore, its transcription may have been in part directly stimulated by PPAR $\alpha$ activation. An up-regulation of SCD which catalyses the formation of MUFA from SFA has also been observed in pigs treated with clofibrate (Cheon et al. 2005). These findings of the effects of the oxidised fat on gene expression of lipogenic enzymes observed in pigs are opposite to those observed in rats in which a dietary oxidised fat causes a down-regulation of lipogenic enzymes and a strong reduction of liver and plasma TAG (Eder \& Kirchgessner, 1998; Eder et al. 2003). 
It is moreover shown that feeding the mildly oxidised fat led to a moderate but significant up-regulation of SREBP-2, and its target genes HMG-CoA-R and LDL receptor, in both liver and small intestine. The present findings suggest that the oxidised fat could have stimulated synthesis and uptake of cholesterol in these tissues. As this effect occurs not only in the liver but also in the small intestine where no PPAR $\alpha$ activation was found in pigs fed the oxidised fat, it is questionable whether these effects are linked to PPAR $\alpha$ activation. The finding that hepatic genes involved in cholesterol synthesis were not altered in pigs treated with clofibrate indeed suggests that PPAR $\alpha$ activation does not influence SREBP-2 controlled transcription of genes involved in cholesterol homeostasis (Cheon et al. 2005). On the other hand, treatment with the PPAR $\alpha$ agonist WY 14,643 caused an up-regulation of genes involved in hepatic cholesterol synthesis in wild-type mice but not in PPAR $\alpha$ null mice, indicating that PPAR $\alpha$ activation indeed could directly stimulate cholesterol synthesis (Knight et al. 2005). It should be noted, however, that there is also another study that found a suppression of gene expression and proteolytic activation of SREBP-2, and a strong down-regulation of its target genes accompanied by reduced cholesterol synthesis in rats (König et al. 2006). The effect of PPAR $\alpha$ activation on SREBP-2-dependent cholesterol synthesis is not yet clear and may also be different between various species. Besides an up-regulation of genes involved in synthesis and uptake of cholesterol, we found a down-regulation of CYP7, the key enzyme of bile acid formation, in the liver. It has been shown in human and rat liver cells that PPAR $\alpha$ agonists lower CYP7 expression probably by reducing the availability of hepatic nuclear factor $4 \alpha$ which is required for binding to a DR-1 in CYP7 promoter (Marrapodi \& Chiang, 2000; Patel et al. 2000). Therefore, we assume that down-regulation of CYP7 in the liver of pigs fed the oxidised fat was caused by PPAR $\alpha$ activation induced by the oxidised fat. Increased hepatic cholesterol synthesis and uptake of cholesterol into the liver, together with a decreased bile acid synthesis, is expected to increase hepatic cholesterol concentration. In contradiction to this, liver and plasma cholesterol concentrations were unchanged in pigs fed the oxidised fat compared to pigs fed the fresh fat. We assume that the changes in gene expression were too small to induce phenotypical alterations of cholesterol concentrations.

In conclusion, the present study shows that a mildly oxidised fat causes PPAR $\alpha$ activation in the liver of pigs as indicated by an increased peroxisome count, a moderate up-regulation of PPAR $\alpha$ target genes and a stimulation of ketogenesis. Moreover, the oxidised fat led to an up-regulation of the expression of SREBP-1 and SREBP-2 and their target genes involved in TAG and cholesterol synthesis, suggesting a stimulation of lipid synthesis. As the fat used in the present study was even less oxidised than fats used for deep-frying of foods, and as there exists a similarity in the gene response to PPAR $\alpha$ agonists between pig and human liver cells, deep-fried fats could exert similar effects in man.

\section{Acknowledgements}

Sebastian Luci and Bettina König contributed equally to this work.

\section{References}

Aebi HE (1986) Catalase. In Methods of Enzymatic Analysis, 3rd ed. pp. 273-286 [HU Bergemeyer, editor]. Weinheim, Germany: VCH Verlagsgesellschaft mbH.

Ameen C, Edvardsson U, Ljungberg A, Asp L, Akerblad P, Tuneld A, Olofsson SO, Linden D \& Oscarsson J (2005) Activation of peroxisome proliferator-activated receptor alpha increases the expression and activity of microsomal triglyceride transfer protein in the liver. J Biol Chem 280, 1224-1229.

Ammouche A, Rouaki F, Bitam A \& Bellal MM (2002) Effect of ingestion of thermally oxidized sunflower oil on the fatty acid composition and antioxidant enzymes of rat liver and brain in development. Ann Nutr Metab 46, 268-275.

Atalay M, Laaksonen DE, Khanna S, Kaliste KE, Hanninen O \& Sen CK (2000) Vitamin E regulates changes in tissue antioxidants induced by fish oil and exercise. Med Sci Sports Exerc 32, 601-607.

Brandsch C, Ringseis R \& Eder K (2002) High dietary iron concentrations enhance the formation of cholesterol oxidation products in the liver of adult rats fed salmon oil with minimal effects on antioxidant status. J Nutr 132, 2263-2269.

Braissant O, Foufelle F, Scotto C, Dauca M \& Wahli W (1996) Differential expression of peroxisome proliferator-activated receptors (PPARs): tissue distribution of PPAR-alpha, -beta, and -gamma in the adult rat. Endocrinology 137, 354-366.

Chao P-M, Chao C-Y, Lin F-J \& Huang C-J (2001) Oxidized frying oil up-regulates hepatic acyl-CoA oxdase and cytochrome P450 4A1 genes in rats and activates PPAR $\alpha . J$ Nutr 131, 3166-3174.

Chao PM, Hsu SC, Lin FJ, Li YJ \& Huang CJ (2004) The up-regulation of hepatic acyl-CoA oxidase and cytochrome P450 4A1 mRNA expression by dietary oxidized frying oil is comparable between male and female rats. Lipids 39, 233-238.

Chao PM, Yang MF, Tseng YN, Chang KM, Lu KS \& Huang CJ (2005) Peroxisome proliferation in liver of rats fed oxidized frying oil. J Nutr Vitaminol (Tokyo) 51, 361-368.

Cheon Y, Nara TY, Band MR, Beever JE, Wallig MA \& Nakamura MT (2005) Induction of overlapping genes by fasting and a peroxisome proliferator in pigs: evidence of functional PPAR $\alpha$ in nonproliferating species. Am J Physiol Regul Integr Comp Physiol 288, R1525-R1535.

Chinetti-Gbaguidi G, Rigamonti E, Helin L, Mutka AL, Lepore M, Fruchart JC, Clavey V, Ikonen E, Lestavel S \& Staels B (2005) Peroxisome proliferator-activated receptor alpha controls cellular cholesterol trafficking in macrophages. J Lipid Res 46, 2717-2725.

Cohn JS (2002) Oxidized fat in the diet, postprandial lipaemia and cardiovascular disease. Curr Opin Lipidol 13, 19-24.

Darimont C, Gradoux N, Cumin F, Baum HP \& De Pover A (1998) Differential regulation of intestinal and liver fatty acid-binding proteins in human intestinal cell line (Caco-2): role of collagen. Exp Cell Res 244, 441-447.

De Hoff JL, Davidson JH \& Kritchevsky V (1978) An enzymatic assay for determining free and total cholesterol in tissues. Clin Chem 24, 433-435.

Delerive P, Furman C, Teissier E, Fruchart JC, Duriez P \& Staels B (2000) Oxidized phospholipids activate PPAR alpha in a phospholipase A2-dependent manner. FEBS Lett 471, 34-38.

Deutsche Gesellschaft für Fettwissenschaft (1994) Einheitsmethoden zur Untersuchung von Fetten, Fettprodukten, Tensiden und verwandten Stoffen. Stuttgart: Wissenschaftliche Verlagsgesellschaft.

Dietschy JM, Turley SD \& Spady DK (1993) Role of liver in the maintenance of cholesterol and low density lipoprotein homeostasis in different animal species, including humans. J Lipid Res 34, $1637-1659$.

Eder K (1999) The effects of a dietary oxidized oil on lipid metabolism in rats. Lipids 34, 717-725. 
Eder K, Keller U \& Brandsch C (2004) Effects of a dietary oxidized fat on cholesterol in plasma and lipoproteins and the susceptibility of low-density lipoproteins to lipid peroxidation in guinea pigs fed diets with different concentrations of vitamins $\mathrm{E}$ and C. Int J Vitam Nutr Res 74, 11-20.

Eder K \& Kirchgessner M (1998) The effect of dietary vitamin E supply and a moderately oxidized oil on activities of hepatic lipogenic enzymes in rats. Lipids 33, 277-283.

Eder K, Schleser S, Becker K \& Körting R (2003) Conjugated linoleic acids lower the release of eicosanoids and nitric oxide from human aortic endothelial cells. J Nutr 133, 4083-4089.

Endo Y, Li CM, Tagiri-Endo M \& Fujimoto K (2001) A modified method for the estimation of total carbonyl compounds in heated and frying oils using 2-propanol as a solvent. J Am Oil Chem Soc 78, 1021-1024.

Fan MZ, Matthews JC, Etienne NM, Stoll B, Lackeyram D \& Burrin DG (2004) Expression of apical membrane L-glutamate transporters in neonatal porcine epithelial cells along the small intestinal crypt-villus axis. Am J Physiol Gastrointest Liver Physiol 287, G385-G398.

Frankel EN (1998) Lipid Oxidation. Dundee: The Oily Press.

Frankel E, Smith L, Hamblin C, Creveling R \& Clifford A (1984) Occurrence of cyclic fatty acid isomers in frying fats used for fast foods. J Am Oil Chem Soc 61, 87-90.

Guo Q, Wang PR, Milot DP, Ippolito MC, Hernandez M, Burton CA, Wright SD \& Chao Y (2001) Regulation of lipid metabolism and gene expression by fenofibrate in hamsters. Biochim Biophys Acta 1533, 220-232.

Habig WH, Pabst MJ \& Jakoby WB (1974) Glutathione S-transferases. The first enzymatic step in mercapturic acid formation. $J$ Biol Chem 249, 7130-7139.

Hara A \& Radin NS (1978) Lipid extraction of tissues with a low-toxicity solvent. Anal Biochem 90, 420-426.

Holden PR \& Tugwood JD (1999) Peroxisome proliferator-activated receptor alpha: role in rodent liver cancer and species differences. $J$ Mol Endocrinol 22, 1-8.

Huang C-J, Cheung N-S \& Lu V-R (1988) Effects of deteriorated frying oil and dietary protein levels on liver microsomal enzymes in rats. J Am Oil Chem Soc 65, 1796-1803.

Keller U, Brandsch C \& Eder K (2004a) The effect of dietary oxidized fats on the antioxidant status of erythrocytes and their susceptibility to haemolysis in rats and guinea pigs. J Anim Physiol Anim Nutr 88, 59-72.

Keller U, Brandsch C \& Eder K (2004b) Supplementation of vitamins $\mathrm{C}$ and $\mathrm{E}$ increases the vitamin $\mathrm{E}$ status but does not prevent the formation of oxysterols in the liver of guinea pigs fed an oxidised fat. Eur J Nutr 43, 353-359.

Knight BL, Hebbach A, Hauton D, Brown AM, Wiggins D \& Patel DD (2005) A role for PPAR $\alpha$ in the control of SREBP activity and lipid synthesis in the liver. Biochem J 389, 413-421.

König B \& Eder K (2006) Differential action of 13-HPODE on PPAR $\alpha$ downstream genes in rat Fao and human HepG2 hepatoma cell lines. J Nutr Biochem 17, 410-418.

König B, Koch A, Spielmann J, Hilgenfeld C, Stangl GI \& Eder K (2006) Activation of PPAR $\alpha$ lowers synthesis and concentration of cholesterol by reduction of nuclear SREBP-2. Biochem Pharmacol (Epublication ahead of print version).

Kubow S (1992) Routes of formation and toxic consequences of lipid oxidation products in foods. Free Radical Biol Med 12, 63-81.

Lemberger T, Braissant O, Juge-Aubry C, Keller H, Saladin R, Staels B, Auwerx J, Burger AG, Meier CA \& Wahli W (1996) PPAR tissue distribution and interactions with other hormone-signaling pathways. Ann NY Acad Sci 27, 231-251.

Lindsay CA \& Wilson JD (1965) Evidence for a contribution by the intestinal wall to the serum cholesterol in the rat. J Lipid Res 6 , $173-181$
Liu JF \& Huang CJ (1995) Tissue $\alpha$-tocopherol retention in male rats is compromised by feeding diets containing oxidized frying oil. J Nutr 125, 3071-3080.

Liu JF \& Huang CJ (1996) Dietary oxidized frying oil enhances tissue $\alpha$-tocopherol depletion and radioisotope tracer excretion in vitamin E-deficient rats. J Nutr 126, 2227-2235.

Liu JF \& Lee Y-W (1998) Vitamin C supplementation restores the impaired vitamin $\mathrm{E}$ status of guinea pigs fed oxidised frying oil. J Nutr 128, 116-122.

Mandard S, Muller M \& Kersten S (2004) Peroxisome proliferatoractivated receptor $\alpha$ target genes. Cell Mol Life Sci 61, 393-416.

Marklund S \& Marklund G (1974) Involvement of the superoxide anion radical in the autoxidation of pyrogallol and a convenient assay for superoxide dismutase. Eur J Biochem 47, 469-474.

Marrapodi M \& Chiang JY (2000) Peroxisome proliferator-activated receptor alpha (PPARalpha) and agonist inhibit cholesterol 7alphahydroxylase gene (CYP7A1) transcription. J Lipid Res 41, 514-520.

Miller CW \& Ntambi JM (1996) Peroxisome proliferators induce mouse liver stearoyl-CoA desaturase 1 gene expression. Proc Natl Acad Sci U S A 93, 9443-9448.

Mishra A, Chaudhary A \& Sethi S (2004) Oxidized omega-3 fatty acids inhibit NF-KB activation via a PPAR $\alpha$-dependent pathway. Arterioscl Thromb Vasc Biol 24, 1621-1627.

Mochizuki K, Suruga K, Yagi E, Takase S \& Goda T (2001) The expression of PPAR-associated genes is modulated through postnatal development of PPAR subtypes in the small intestine. Biochim Biophys Acta 1531, 68-76.

Motojima K, Passilly P, Peters JM, Gonzalez FJ \& Latruffe N (1998) Expression of putative fatty acid transporter genes are regulated by peroxisome proliferator-activated receptor alpha and gamma activators in a tissue- and inducer-specific manner. $J$ Biol Chem 273, $16710-16714$

Paglia DE \& Valentine WN (1967) Studies on the quantitative and qualitative characterization of erythrocyte glutathione peroxidase. J Lab Clin Med 70, 158-169.

Patel DD, Knight BL, Soutar AK, Gibbons GF \& Wade DP (2000) The effect of peroxisome-proliferator-activated receptor-alpha on the activity of the cholesterol 7 alpha-hydroxylase gene. Biochem $J$ 351, 747-753.

Patel DD, Knight BL, Wiggins D, Humphries SM \& Gibbons GF (2001) Disturbances in the normal regulation of SREBP-sensitive genes in PPAR alpha-deficient mice. J Lipid Res 42, 328-337.

Peffer PL, Lin X \& Odle J (2005) Hepatic $\beta$-oxidation and carnitine palmitoyltransferase I in neonatal pigs after dietary treatments of clofibric acid, isoproterenol, and medium-chain triglycerides. Am J Physiol Regul Integ Comp Physiol 288, R1518-R1524.

Peters JM, Cheung C \& Gonzalez FJ (2005) Peroxisome proliferatoractivated receptor-alpha and liver cancer: where do we stand? J Mol Med 83, 774-785.

Pfaffl MW (2001) A new mathematical model for relative quantification in real-time RT-PCR. Nucleic Acids Res 29, e45.

Recknagel RO \& Glende EA Jr (1984) Spectrophotometric detection of lipid conjugated dienes. Methods Enzymol 105, 331-337.

Royall JA \& Ischiropoulos H (1993) Evaluation of 2',7'-dichlorofluorescin and dihydrorhodamine 123 as fluorescent probes for intracellular $\mathrm{H}_{2} \mathrm{O}_{2}$ in cultured endothelial cells. Arch Biochem Biophys 302, 348-355.

Ruiz-Gutierrez V, Perez-Espirosa A, Vazquez CM \& Santa-Maria C (1999) Effects of dietary fats (fish, olive and high-oleic-acid sunflower oils) on lipid composition and antioxidant enzymes in rat liver. Br J Nutr 82, 233-241.

Schoonjans K, Staels B \& Auwerx J (1996) The peroxisome proliferator activated receptors (PPARs) and their effects on lipid metabolism and adipocyte differentiation. Biochim Biophys Acta 1302, 93-109. 
Shakir KM, Sundaram SG \& Margolis S (1978) Lipid synthesis in isolated intestinal cells. J Lipid Res 19, 433-442.

Sidwell CG, Salwin H, Benca M \& Mitchell JH Jr (1954) The use of thiobarbituric acid as a measure of fat oxidation. J Am Oil Chem Soc 31, 603-606.

Staprans I, Pan XM, Rapp JH \& Feingold KR (2005) The role of dietary oxidized cholesterol and oxidized fatty acids in the development of atherosclerosis. Mol Nutr Food Res 49, 1075-1082.

Sülzle A, Hirche F \& Eder K (2004) Thermally oxidized dietary fat upregulates the expression of target genes of PPAR alpha in rat liver. J Nutr 134, 1375-1383.
Walrand S, Valeix S, Rodriguez C, Ligot P, Chassagne J \& Vasson MP (2003) Flow cytometry study of polymorphonuclear neutrophil oxidative burst: a comparison of three fluorescent probes. Clin Chim Acta 331, 103-110.

Yoshida H \& Kajimoto G (1989) Effect of dietary vitamin E on the toxicity of autoxidized oil to rats. Ann Nutr Metab 33, $153-161$.

Yu XX, Odle J \& Drackley JK (2001) Differential induction of peroxisomal $\beta$-oxidation enzymes by clofibric acid and aspirin in piglet tissues. Am J Physiol Regul Integr Comp Physiol 281, R1553-R1561. 